\title{
$\mathrm{PH} 104_{\text {debate }}$
}

a debate Patrimonio cultural y cambio climático

| coordina Alejandro García Hermida

\section{Aprender de la arquitectura anónima}

\author{
Olga Muñoz i Frigola | Associació GRETA \\ URL de la contribución <www.iaph.es/revistaph/index.php/revistaph/article/view/4992>
}

El origen de GRETA (Grupo de Recuperación y Estudio de la Tradición Arquitectónica), en el año 2011, se debió sobre todo a la preocupación por el estado del patrimonio más débil y menos protegido, lo que llamamos la arquitectura tradicional, popular o anónima. Fue su continua y paulatina desaparición, tanto por derribos como por intervenciones que la desvirtuaban, lo que nos llevó a estudiar, difundir y aportar todo lo que estuviera en nuestras manos en el intento de frenar tan triste proceso. Desde un inicio nuestra atención se centró en el estudio de las técnicas tradicionales y los materiales utilizados para construir este patrimonio como primera vía para su puesta en valor y conservación. Después de diez años de recorrido, profundizar en la arquitectura tradicional nos ha traído muchos efectos colaterales positivos. Todos ellos conocimientos muy útiles para una mayor sostenibilidad ambiental, sí, pero también para la tan necesaria sostenibilidad económica y social.

La arquitectura tradicional se construía con los recursos del lugar para responder a unas necesidades concretas definidas por un territorio y un clima específicos. Optimizar los recursos disponibles para obtener el máximo confort con el mínimo derroche de energía es exactamente la premisa necesaria para luchar contra el cambio climático. Para disminuir el calentamiento global se requiere reducir la emisión de $\mathrm{CO}_{2}$, y una buena vía para hacerlo es focalizar la inversión en el conocimiento de las personas y en su saber hacer en vez de invertir en el consumo de bienes fruto de largos procesos industriales que requieren buenas dosis de energía no renovable y contaminante, y largas distancias de transporte.

Esta es una de las mayores lecciones que nos da la arquitectura tradicional, pero, desgraciadamente, parte del conocimiento que la ha hecho posible se ha perdido. La trasmisión oral, establecida generación tras gene- ración, se vio interrumpida durante el último siglo, nos pareció que era un conocimiento superado y prescindible. Y aunque actualmente esta percepción ha perdido adeptos, encontrar testimonios para recuperar lo perdido no siempre es posible.

Desde GRETA ${ }^{1}$ entendemos el patrimonio construido como una fuente de información, como material donde extraer conocimiento incorporado cuando no se encuentra la fuente directa. Por este motivo, en los últimos años, estamos inmersos en el trabajo de campo. Nuestro primer territorio de estudio ha sido Les Gavarres, y más recientemente hemos incorporado la Alta Garrotxa y el Cap de Creus. Las tres zonas son áreas naturales protegidas de la provincia de Girona.

Zonas justamente escogidas porque uno de los ámbitos en que la arquitectura tradicional está más desatendida es en los espacios naturales protegidos. Posiblemente su riqueza en biodiversidad tiene que ver con su inaccesibilidad, consecuencia de una orografía muy accidentada. Son territorios que habían estado mucho más poblados de lo que lo están en la actualidad, con un modo de vida estrechamente vinculado a la agricultura y ganadería, que han sufrido en los últimos decenios el éxodo de gran parte de su población, con el correspondiente abandono de hogares.

Desde este año 2021 y hasta el 2023 dedicaremos gran parte de nuestros esfuerzos a analizar la arquitectura anónima de estos tres territorios, gracias al proyecto El patrimonio arquitectónico anónimo de los espacios naturales protegidos, dentro del PECT (programa de proyectos de especialización y competitividad territorial) Girona, patrimonio activo, que cuenta con el apoyo y financiación de la Diputació de Girona, de la Generalitat de Catalunya y de fondos europeos. 
El objetivo es estudiar la arquitectura tradicional de estas tres áreas, cercanas pero muy distintas entre sí. Con recursos disponibles específicos en cada una de ellas, debido tanto al diferente sustrato geológico como a los diversos microclimas, según su relación y posición respecto a los Pirineos y el litoral marítimo.

Para sacar el máximo provecho del conocimiento incorporado en el propio patrimonio y su entorno domesticado, se cuenta con la colaboración de especialistas de todas las disciplinas relacionadas con el territorio, su historia y los oficios propios de la construcción: historiadores, arqueólogos, arquitectos, geólogos; y profesionales y artesanos como restauradores, carpinteros, ceramistas, etc.

El estudio se completará con talleres realizados en obra real, con la restauración de elementos patrimoniales, utilizando las mismas técnicas con las que fueron construidos. La formación continua de técnicos y constructores resulta indispensable para mejorar la calidad día a día, y no se debe menospreciar el efecto divulgativo y de puesta en valor del patrimonio que tienen este tipo de actividades en espacios de uso público. Los mencionados talleres cuentan con profesorado diverso y alumnado plural, los futuros responsables tanto de la concepción como de la ejecución de las obras. Esta experiencia, ampliamente probada desde nuestros primeros cursos en 2014, ha llevado a establecer una red de contactos muy fructífera y estimulante. Porque para poder cambiar la manera de hacer, y aprender cómo se puede construir con materiales y técnicas más saludables y sostenibles, se necesita la complicidad de todos y cada uno de los actores que intervienen en las obras.

Todo este aprendizaje que nos permite el estudio del patrimonio arquitectónico va más allá del propiamente constructivo o de materiales. En el proceso de "reaprender" conocimientos específicos nos damos cuenta que se trata de otra manera de hacer, de otra manera de trabajar y de relacionarse con el contexto. Nos referimos tanto a la relación con el territorio más próximo, ya que el uso de los recursos disponibles cercanos requiere tener

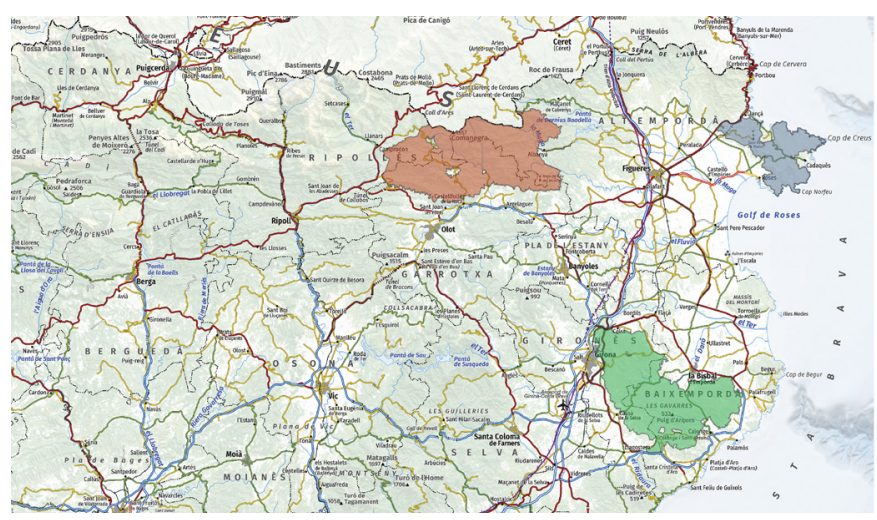

Áreas de estudio del proyecto El patrimonio arquitectónico anónimo en los espacios naturales protegidos, llevado a cabo por GRETA

un buen conocimiento del entorno, como a las relaciones humanas y laborables, que pasan a basarse en la confianza y el saber hacer.

Lo que comenzó inicialmente con la intención de cuidar y respetar el patrimonio arquitectónico y, de esa manera, traspasarlo a las siguientes generaciones manteniendo su espíritu y carácter, finalmente nos ha mostrado el camino de cómo podemos vivir y construir de otra manera. Significa un cambio de valores que afecta a toda nuestra actividad y, por lo tanto, puede tener un efecto exponencial en la lucha contra el cambio climático.

\section{NOTAS}

1. Redes Sociales del proyecto GRETA: https://www. projectegreta.cat/ca/; https://www.facebook.com/projectegreta; https://www.instagram.com/projectegreta/; https://twitter.com/projectegreta 